\title{
Study of Haematological Profile of Thalassemia Patients With Reference To High Performance Liquid Chromatography
}

\author{
Authors \\ Huma Khan ${ }^{1}$, Juned Shaikh ${ }^{2}$, Neela Kumbhakarna ${ }^{3}$ \\ ${ }^{1}$ Assistant Professor Pathology, Jawaharlal Nehru Medical College, Wardha \\ ${ }^{2}$ Assistant Professor Urosurgery, Jawaharlal Nehru Medical College, Wardha \\ ${ }^{3}$ Professor of Pathology, Government Medical College, Aurangabad \\ Corresponding Author \\ Dr Huma Khan \\ M3-5, Meghdootam Apartments, JNMC College Campus, (DMIMS) Sawangi, \\ Wardha - 442001, Maharashtra state, India \\ Contact details*-Phone Numbers: +91-9371721782, + 91-9820234273 \\ Email: humathegreat@gmail.com,junedahmed@gmail.com
}

\begin{abstract}
Study of Haematological Profile of Thalassemia Patients With Reference To High Performance Liquid Chromatography

Objective: Beta thalassemia and their interaction with structural $H b S$ and $H b E$ variants are major public health problem in India. This study was carried out to assess the usefulness of HPLC in diagnosis of thalassemia patients and its variants.

Methodology: 209 thalassemia cases during 2.4 year period were investigated.CBC, peripheral smear,

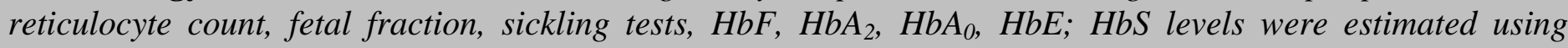
BIORAD variant automated HPLC technique.

Results: Out of 209 cases, thalasssemia trait was the most common followed by thalassemia major, HbS $\beta$ thalassemia trait, HbE $\beta$ thalassemia trait, thalassemia intermedia, $\delta \beta$ thalassemia trait. Buddha community (34.93\%) was the most common ethnic group. Consanguinity of $21.53 \%$ was observed. The various haemoglobin levels were studied in these groups.

Conclusion: HPLC was found to be simple, rapid and reliable method for detection of thalassemia. Consanguinity of $21.53 \%$ highlights the role of premarital counselling in thalassemia patients especially in Buddha and Muslim communities. This emphasises the need of community based targeted awareness, counselling and field work in these cases which is possible by using HPLC.
\end{abstract}

Keywords: Thalassemia, HPLC, $\mathrm{HbS}, \mathrm{HbE}$.

\section{Introduction}

The term "thalassemia" is derived from the Greek, thalassa (sea) and haima (blood). Beta thalassemia syndromes are group of hereditary blood disorders characterised by reduced or absent beta globin chain synthesis. Most thalassemias are inherited as recessive traits ${ }^{[1]}$. In India the mean prevalence of beta thalassemia gene is $3.3 \%$ and 6000 to 8000 children are born every year with thalassemia major ${ }^{[2]}$. The $\beta$ thalassemias and their interaction 
with structural haemoglobin $(\mathrm{Hb})$ variants like $\mathrm{HbS}$ and $\mathrm{HbE}$ are a major public health problem in India ${ }^{[3]}$. Automated cation-exchange high performance liquid chromatography (HPLC) has emerged as an excellent screening and diagnostic tool for diagnosing beta thalassemias ${ }^{[4]}$.

\section{Materials and Method}

The main objectives of this study were:

1. To study clinical features, haematological parameters and HPLC findings in patients of thalassemia.

2. To generate data regarding ethnicity and consanguinity in these patients

3. To evaluate the role of family study.

The present study is a cross-sectional descriptive study conducted in Government Medical College, Aurangabad over 2.4 year duration. Inclusion criteria included patients with positive fetal fraction test, patients with clinical diagnosis/ suspicion of thalassemia on haematological workup and family members of these patients. The patients who received blood transfusion in the last 6 months were excluded from the study. A specific algorithm was followed in the study:

1. Haematological profile of cases was done. It included CBC (complete blood count), PS (peripheral smear), reticulocyte count, fetal fraction, and sickling test. BM (bone marrow) was done whenever required.

2. Using AUTOMATED BIORAD VARIANT HPLC, percentage levels of $\mathrm{HbF}, \mathrm{HbA}_{2}, \mathrm{HbA}_{0}$, $\mathrm{HbS}, \mathrm{HbE}$ were estimated to diagnose the cases. Repeat HPLC after complete vitamin B12 therapy/iron therapy were done in some cases. (Specific elution windows are defined for abnormal haemoglobins like $\mathrm{HbS}, \mathrm{HbD}$ and $\mathrm{HbE}$ using the $\beta$ thalassemia short program)

3. Study of family members whenever possible was done to confirm the diagnosis and to determine ethnic background and consanguinity.

\section{Results}

Table No 1: Cases grouped as:

\begin{tabular}{|c|c|c|c|c|c|c|c|}
\hline Group & $\begin{array}{c}\text { Gr-A } \\
\text { Thal major } \\
\text { (TM) }\end{array}$ & $\begin{array}{c}\text { Gr-B } \\
\text { Thal trait } \\
\text { (TT) }\end{array}$ & $\begin{array}{c}\text { Gr-C } \\
\text { S beta thal } \\
\text { trait } \\
(\mathrm{S} \beta T T)\end{array}$ & $\begin{array}{c}\text { Gr-D } \\
\text { E beta thal } \\
\text { trait } \\
(\mathrm{E} \beta \mathrm{TT})\end{array}$ & $\begin{array}{c}\text { Gr-Rare } \\
\text { Thal Inter } \\
\text { (TI) }\end{array}$ & $\begin{array}{c}\text { Gr-Rare } \\
\text { Delta beta } \\
\text { thal trait } \\
(\delta \beta T T)\end{array}$ & TOTAL \\
\hline $\begin{array}{l}\text { No } \\
\text { of cases }\end{array}$ & $\begin{array}{c}35+1 * \\
\text { Total=36 } \\
(17.22 \%)\end{array}$ & $\begin{array}{c}108+23^{*} \\
\text { Total }=131 \\
(62.68 \%)\end{array}$ & $\begin{array}{c}29+1 * \\
\text { Total=30 } \\
(14.35 \%)\end{array}$ & $\begin{array}{c}5+1^{*} \\
\text { Total }=6 \\
(2.87 \%)\end{array}$ & $\begin{array}{c}2+1^{*} \\
\text { Total }=3 \\
(1.44 \%)\end{array}$ & $\begin{array}{c}3 \\
\text { Total=3 } \\
(1.44 \%)\end{array}$ & $\begin{array}{c}182+27^{*} \\
=209\end{array}$ \\
\hline
\end{tabular}

Gr-Group.

Note: (Cases marked by $\left(^{*}\right)$ were provisionally diagnosed without family study)

Cases with $\left(\mathrm{HbA}_{2}>3.9 \%\right)$ were provisionally diagnosed as thalassemia trait ${ }^{[5,6]}$.

Out of 209 cases of thalassemia maximum cases were of thalassemia trait (TT) 131 cases $(62.68 \%)$ and the other group wise case distribution is as above. In $182(87.08 \%)$ cases family study was performed and in 27 (12.92\%) cases family study was not possible. Reasons for incomplete family studies were poor socio-economic status, distance, lack of awareness, remarriage/death, reluctance (especially in father), alcoholism and psychosocial reasons.
AGE: In thalassemia major all the cases were in 0-10 years of age group (the average of presentation was $1.6 \mathrm{yrs})$. In thalassemia trait, maximum cases were in 21-30 years of age group, because this group was mostly comprised of parents of an affected child. In sickle beta thalassemia trait maximum cases were in 11-20 years of age group. In $\mathrm{HbE}$-beta thalassemia trait maximum 4 cases were in 11-30 years of age group. In thalassemia intermedia 1 case was in $0-10 \mathrm{yrs}$ age group, 2 cases in 11-20 yrs group and in delta 
beta thalassemia trait 3 cases were in 21-30 yrs of age group.

SEX: Overall there were 101 males $(48.33 \%)$ and 108 females $(51.67 \%)$ in the present study.

ETHNIC BACKGROUND: Buddha (34.93\%) was the most common ethnic background among all groups followed by Muslims (16.27\%), Mahar and Banjara (9.09\% each); Maratha (8.13\%), less common were Koli, Mang and Sindhis.

\section{Consanguinity}

It was observed in 45 (21.53\%) cases. Maximum cases of consanguinity were seen in Muslims 20 (44.44\%) followed by Buddha community 17 $(37.78 \%)$.

\section{CLINICAL PRESENTATION}

Table No 2: Clinical Presentation of cases among all groups:

\begin{tabular}{|c|c|c|c|c|c|c|c|c|c|c|c|c|c|}
\hline $\begin{array}{l}\text { Clinical } \\
\text { Features }\end{array}$ & \multicolumn{2}{|c|}{$\begin{array}{c}\text { Gr-A } \\
\text { TM } \\
\mathrm{T}=36\end{array}$} & \multicolumn{2}{|c|}{$\begin{array}{c}\text { Gr-B } \\
\text { TT } \\
T=131\end{array}$} & \multicolumn{2}{|c|}{$\begin{array}{l}\text { Gr-C } \\
\text { S } \beta \text { TT } \\
\mathrm{T}=30\end{array}$} & \multicolumn{2}{|c|}{$\begin{array}{c}\text { Gr-D } \\
\text { EßTT } \\
T=6\end{array}$} & \multicolumn{2}{|c|}{$\begin{array}{c}\text { Gr-Rare } \\
\text { TI } \\
\mathrm{T}=3\end{array}$} & \multicolumn{2}{|c|}{$\begin{array}{c}\text { Gr-Rare } \\
\delta \beta T T \\
\mathrm{~T}=3\end{array}$} & $\begin{array}{l}\text { Total } \\
=209\end{array}$ \\
\hline & $\mathrm{N}$ & $\%$ & $\mathrm{n}$ & $\%$ & $\mathrm{~N}$ & $\%$ & $\mathrm{n}$ & $\%$ & $\mathrm{n}$ & $\%$ & $\mathrm{n}$ & $\%$ & \\
\hline Pallor & 36 & 100 & 58 & 44.27 & 25 & 83.33 & 6 & 100 & 2 & 66.67 & 2 & 66.7 & 129 \\
\hline Jaundice & 8 & 22.22 & 1 & 0.76 & 11 & 36.66 & 1 & 16.66 & 2 & 66.67 & 1 & 33.3 & 24 \\
\hline VOC & - & - & - & - & 7 & 23.33 & - & - & - & - & - & - & 7 \\
\hline Abdo pain & 9 & 25 & 2 & 1.52 & 6 & 20 & 1 & 16.66 & 1 & 33.3 & - & - & 19 \\
\hline Leg ulcer & 2 & 5.55 & - & - & 1 & 3.33 & 1 & 16.66 & 1 & 33.3 & - & - & 5 \\
\hline
\end{tabular}

Majority of cases presented clinically as pallor $(\mathrm{Hb}<10 \mathrm{gm} \%)$ in all the groups followed by jaundice, abdominal pain. Leg ulcer was not seen in thalassemia trait group and $\delta \beta T T$ group. Vasoocclusive crisis (VOC) was seen only in S $\beta \mathrm{TT}$ (23.33\%). 71 cases $(33.97 \%)$ cases had splenomegaly (abnormal enlargement of spleen confirmed by clinical examination). 44 cases $(21.05 \%)$ presented with hepatomegaly (abnormal enlargement of liver confirmed by clinical examination).

The thalassemia trait group was divided further-

Table No 3-

\begin{tabular}{|l|c|c|}
\hline Thalassemia Trait Group & Parents of affected child & Non-Parent group \\
\hline Total =131 cases & 108 & 23 \\
\hline
\end{tabular}

A specific algorithm was followed for the 23 cases of newly diagnosed thalassemia trait group. When HbA2 level of $>3.9 \%$ was detected after HPLC test, it was confirmed by a repeat HPLC test. In all these cases an attempt to exclude other causes of increase $\mathrm{HbA}_{2}$ was made by- $\mathrm{CBC}$, PS, haemolytic fractions, BM examination, thyroid profile, HIV test, and repeat HPLC after complete treatment of megaloblastic anemia with vitamin B12 therapy was done whenever required. After the above procedure these cases were classified as thalassemia trait.
Exclusion of other causes of decreased $\mathrm{HbA}_{2}$ from $\delta \beta T T$ patients was done by-CBC; PS, haemolytic fractions, $\mathrm{BM}$ examination, iron profile and repeat HPLC test after 3 months of complete iron therapy were done whenever required. After the above procedure the cases were classified as $\delta \beta T T$ patients based upon $\mathrm{HbA}_{2}$ and $\mathrm{HbF}$ levels detected by HPLC. 
Table No 4. Mean haematological parameters in all groups:

\begin{tabular}{|l|l|l|l|l|l|l|}
\hline Parameters & $\begin{array}{l}\text { Group-A } \\
\text { TM }\end{array}$ & $\begin{array}{l}\text { Group-B } \\
\text { TT }\end{array}$ & $\begin{array}{l}\text { Group-C } \\
\text { S } \beta \text { thal trait }\end{array}$ & $\begin{array}{l}\text { Group-D } \\
\text { E } \beta \text { thal trait }\end{array}$ & $\begin{array}{l}\text { Group-Rare } \\
\text { TI }\end{array}$ & $\begin{array}{l}\text { Group Rare } \\
\delta \beta T T\end{array}$ \\
\hline $\mathrm{Hb}$ (gm \%) & $5.48 \pm 1.45$ & $10.39 \pm 1.46$ & $7.97 \pm 1.98$ & $8.03 \pm 1.13$ & $7.97 \pm 0.84$ & $10.5 \pm 1.9$ \\
\hline RBC count (million/cu.mm) & $3.24 \pm 1.02$ & $4.43 \pm 0.72$ & $4.03 \pm 1.03$ & $4.23 \pm 0.80$ & $3.7 \pm 0.26$ & $4.97 \pm 0.50$ \\
\hline PCV (\%) & $17.05 \pm 4.61$ & $31.10 \pm 5.24$ & $25.15 \pm 5.57$ & $25.65 \pm 3.03$ & $23.4 \pm 1.97$ & $30.5 \pm 5.31$ \\
\hline MCV (fl) & $62.41 \pm 5.83$ & $76.29 \pm 8.15$ & $75.6 \pm 8.11$ & $74.17 \pm 7.005$ & $64.8 \pm 3.64$ & $64.18 \pm 3.52$ \\
\hline MCH (pg) & $18.52 \pm 2.99$ & $21.97 \pm 2.91$ & $21.71 \pm 3.59$ & $23.72 \pm 3.57$ & $20 \pm 2.96$ & $21.37 \pm 2.08$ \\
\hline MCHC (gm \%) & $25.04 \pm 4.08$ & $27.66 \pm 3.97$ & $27.80 \pm 3.59$ & $29.05 \pm 0.97$ & $26.9 \pm 4.33$ & $32.77 \pm 2.48$ \\
\hline RDW (\%) & $17.98 \pm 1.88$ & $14.15 \pm 1.23$ & $16.11 \pm 1.96$ & $16.57 \pm 2.73$ & $15.07 \pm 1.07$ & $15.57 \pm 1.35$ \\
\hline
\end{tabular}

*(All figures mentioned are mean $\pm \mathrm{SD}$ ).

Thalassemia major patients had low haemoglobin levels $(5.48 \pm 1.45)$ as compared to the other groups. In thalassemia trait and $\delta \beta \mathrm{TT}$ patients the haemoglobin levels were above $10 \mathrm{gm} \%$. RDW (red cell distribution width) was found to be high in thalassemia major patients $(17.98 \pm 1.88)$ as compared to other groups.

Table No 5. Average haemoglobin levels by HPLC in all groups:

\begin{tabular}{|l|c|c|c|c|c|c|}
\hline & $\begin{array}{c}\text { Group-A } \\
\text { TM }\end{array}$ & $\begin{array}{c}\text { Group-B } \\
\text { TT }\end{array}$ & $\begin{array}{c}\text { Group-C } \\
\text { S } \beta \text { thal trait }\end{array}$ & $\begin{array}{c}\text { Group-D } \\
\text { E } \beta \text { thal trait }\end{array}$ & $\begin{array}{c}\text { Group-Rare } \\
\text { TI }\end{array}$ & $\begin{array}{c}\text { Group-Rare } \\
\delta \beta T T\end{array}$ \\
\hline $\mathrm{HbF}(\%)$ & $92.35 \pm 4.83$ & $0.69 \pm 0.84$ & $17.57 \pm 8.39$ & $19 \pm 12.83$ & $43.47 \pm 0.40$ & $14.47 \pm 1.97$ \\
\hline $\mathrm{HbA}_{0}(\%)$ & $4.86 \pm 4.02$ & $83.58 \pm 2.22$ & $6.44 \pm 6.68$ & $26.43 \pm 15.96$ & $47.9 \pm 0.52$ & $77.47 \pm 2.66$ \\
\hline $\mathrm{HbA}_{2}(\%)$ & $3.46 \pm 1.21$ & $5.57 \pm 0.63$ & $5.27 \pm 0.83$ & & $4.53 \pm 1.44$ & $1.97 \pm 0.50$ \\
\hline $\mathrm{HbS}(\%)$ & - & - & $70.08 \pm 8.76$ & - & - & - \\
\hline $\mathrm{HbE}(\%)$ & - & - & - & $48.43 \pm 10.68$ & - & - \\
\hline
\end{tabular}

In thalassemia major group the average $\mathrm{HbF}$ levels were high; it was $(92.35 \pm 4.83)$.Elevated $\mathrm{HbF}$ levels of $(43.47 \pm 0.40)$ were encountered in thalassemia intermedia patients. The cut off value of $\mathrm{HbA}_{2}>3.9 \%$, was used to diagnose thalassemia trait, after exclusion of the other causes of increase $\mathrm{HbA}_{2}{ }^{[5,6]}$. In thalassemia trait patients the average $\mathrm{HbA} 2$ level was found to be $(5.57 \pm 0.60)$.

\section{Discussion}

Thalassemia trait constituted the commonest disorder with 131 cases $(62.68 \%)$ in the present study. Most of the cases in this group were parents of an affected child. In, thalassemia major group $100 \%$ of cases presented in <10years of age with average age of presentation being 1.6 years which was consistent with Patel $\mathrm{J}$ et al study $(90.65 \%$ $<10$ years $)^{[7]}$. In E $\beta$ TT patient's average age was 20.33 years, S $\beta$ TT 17.7 years and in thalassemia intermedia was 11 years in the present study.

Buddha was the most common caste affected 73 (34.93\%), Muslims (16.27\%), Mahar and Banjara (9.09\% each) in our study. Ambekar SS et al, also found the Navbudha 55 cases (33.5\%) most common ethnicity affected similar to our study followed by Maratha 51 (30.5\%) and Muslims 22 $(13.2 \%)^{[8]}$. Shah SJ et al study stated that 2 out of 2 cases $(100 \%)$ of $\mathrm{HbE} \beta$ thalassemia patients were Muslims and in the present study 3 out of 6 cases $(50 \%)$ of $\mathrm{HbE} \beta$ thalassemia patients were Muslims ${ }^{[9]}$.

Consanguinity was seen in 45 cases out of 209 cases $(21.53 \%)$. This may be due to common practice of consanguineous marriages in Muslim $(44.44 \%)$ and Buddha $(37.78 \%)$ communities. Baig et al (2006) observed that very high (>81\%) consanguinity and low literacy rate were the risk factors for high incidence of $\beta$-thalassemia in South Punjab, because of this there was a need of thalassemia prevention program in this part of Pakistan ${ }^{[10]}$.

Shah SJ et al reported all 35 cases with pallor (100\%), 31 cases with splenomegaly (88.6\%), 25 cases with hepatomegaly $(71.4 \%)$ and 8 cases with icterus $(22.9 \%)^{[9]}$. While in our study, pallor was the commonest presentation seen in 129 cases $(61.72 \%)$ followed by jaundice seen in 24 $(11.48 \%)$, splenomegaly in 71 (33.97\%), hepat- 
omegaly in 44 (21.05\%). Vaso-occlusive crises seen in only $S \beta$ thalassemia trait patients in 7 cases.

Studies by Rao.S et al ${ }^{[6]}$, Patel.J et al ${ }^{[7]}$ observed low haemoglobin levels in $\beta$-thalassemia major $<7 \mathrm{~g} \%$. Similar was the finding in our study, thalassemia major group showed haemoglobin levels of $(5.48 \pm 1.45)$ as compared to the other groups. In Rao.S et al study thalasssemia trait and $\delta \beta$ TT patients the haemoglobin levels were $>10$ gm\%, similar was the findings in these groups in our study. In the present study the HbF level in thalassemia major group was high $>90 \%$ (92.38 \pm 4.83$)$, as compared to the others studies like Gonzalez-Redondo JM et al ${ }^{[11]}$, Rao.S et al ${ }^{[6]}$ Patel J et al ${ }^{[7]}$. C. Vani and S.Mamta ${ }^{[12]}$ where $\mathrm{HbF}$ level was quite variable $<90 \%$. This may be due to, the reason, that the cases included in the present study did not receive any blood transfusion. Fucharoen $\mathrm{S}$ et al study $\mathrm{HbA} 2$ level of $(5.5 \pm 1.26)$ was noted ${ }^{[13]}$. The average $\mathrm{HbA}_{2}$ level in thalassemia trait group in the present study matched with $\mathrm{HbA}_{2}$ level in Rao S. et al study and it was $(5.5 \pm 0.6)$. In C.Vani and S.Mamta HbA2 level was $5.4 \%{ }^{[12]}$.

In Rao S.et al study $\mathrm{HbS}$ level(71.7 \pm 5.8$)$ and $\mathrm{HbF}$ was (18.3 \pm 8.4$)$; in C.Vani and S.Mamta study $\mathrm{HbS}-65.6 \% \mathrm{HbF}-19.2 \%$ were seen ; while in the present study the $\mathrm{HbS}$ level was $(70.08 \pm 8.76)$ and HbF level of $(17.57 \pm 8.39)$ level was found. Thus overall $\mathrm{HbS}$ levels were $>60 \%$ and $\mathrm{HbF}$ levels were $>15 \%$. The average $\mathrm{HbA}_{2}$ level in present study was $(5.27 \pm 0.83)$. In 29 out of 30 cases, family HPLC study supported the diagnosis of double heterozygous S $\beta$ TT.

Average $\mathrm{HbE}$ variant levels, in the present study was $(48.43 \pm 10.68)$ and $\mathrm{HbF}$ level was (19 $\pm 12.83)$. In Rao $\mathrm{S}$ et al study $\mathrm{HbE}$ was (52.3 \pm 17.6) and $\mathrm{HbF}(21.7 \pm 12.2)$; in Jha BM et al $\mathrm{HbE}$ variant level of $57.58 \%$ and $\mathrm{HbF} 25.98 \%$ were observed ${ }^{[14]}$. Thus in all the studies average $\mathrm{HbF}$ levels were approximately $>20 \%$ and average $\mathrm{HbE}$ variant levels were $>40 \%$. In 5 cases the diagnosis was supported by family HPLC study. In present study, on comparing $S \beta$ group and $E \beta$ group, it was seen that the level of abnormal haemoglobin $(\mathrm{HbS} / \mathrm{HbE})$ was more in $\mathrm{S} \beta$ group than E $\beta$ group (HbS-70.08 \pm 8.76 and $\mathrm{HbE}$ $48.43 \pm 10.48)$. The level of $\mathrm{HbF}$ was more in $\mathrm{E} \beta$ group than $\mathrm{S} \beta$ group $(19 \pm 12.83$ in $\mathrm{E} \beta$ and $17.57 \pm 8.39$ in $S \beta)$. Similar was the observation in C.Vani and S.Mamta study ${ }^{[12]}$

According to Sachdev $\mathrm{R}$ et al study in patients of thalasemia intermedia the $\mathrm{HbF}$ levels are raised with a variable reduction in $\mathrm{HbA}_{0}{ }^{[5]}$. In the present study the cases of thalassemia intermedia were classified on the basis of: a) Clinical presentation of these patients being at a later age than thalassemia major. The average age of presentation was 11 years in our study. b) These patients required infrequent blood transfusion (12units/ year). c) Average HbF levels by HPLC were $(43.47 \pm 0.40)$.

However, distinction of various genotypes of thalassemia intermedia is possible by molecular genetic studies. Hence, molecular studies are essential for definitive diagnosis of thalassemia intermedia. Among $\delta \beta$ thalassemia trait, Rao S et al reported $\mathrm{HbF}(13.3 \pm 4.3), \mathrm{HbA} 2-2.8$, while in our study $\mathrm{HbF}$ level was found to be (14.47 \pm 1.97) and HbA2 (1.97 \pm 0.50$)$ levels were observed. Family study was done in all the cases.

\section{Conclusion}

To conclude we found commonest disorder of all the groups was thalassemia trait which constituted $62.68 \%$ of the study, because family study was meticulously done in the present study. All the cases of thalassemia major group presented in first decade. In $\mathrm{S} \beta$ thalassemia group maximum cases were detected in second decade. This reflects that $\mathrm{S} \beta$ thalassemia cases are asymptomatic for longer period of time. Similar findings were seen in $E \beta$ thalassemia, thalassemia intermedia, and $\delta \beta$ thalassemia trait group. Thus, it can be considered that thalassemia major manifests in early childhood while other groups present at later age. Consanguinity was seen in $21.53 \%$ cases. Thus, it implies that the consanguineous marriage increases the frequency of thalassemia, highlighting the 
role of premarital counselling. Buddha (34.93\%) and Muslims (16.27\%) were the most common ethnic groups affected. This emphasises the need to formulate community based studies and to implement strategies to increase the awareness about thalassemia in such communities. Pallor was the commonest presentation seen in 129 cases $(61.72 \%)$ followed by jaundice in 24 cases $(11.48 \%)$ and abdominal pain in 19 cases $(9.09 \%)$. Vaso-occlusive crises were seen in only $\mathrm{S} \beta$ thalassemia group. Maximum cases of splenomegaly and hepatomegaly were seen thalassemia major group followed by $\mathrm{S} \beta$ thalassemia group.

In thalassemia major group, the HPLC levels of $\mathrm{HbF}$ was high $>90 \%(92.38 \pm 4.83)$, in thalassemia trait group, HbA2 level was $(5.5 \pm 0.6)$. On comparing $S \beta$ thalassemia group and $E \beta$ thalassemia group, the percentage of abnormal haemoglobin $(\mathrm{HbS} / \mathrm{HbE})$ was more in $\mathrm{S} \beta$ thalassemia group than $\mathrm{E} \beta$ thalassemia group. The $\mathrm{HbF}$ level was more in $\mathrm{HbE} \beta$ thalassemia group than $\mathrm{HbS} \beta$ thalassemia group.

Family HPLC screening is useful for the diagnosis of difficult cases especially in double heterozygous states. HPLC screening helps to identify thalassemia carrier couples. It alerts them of their risk and options to avoid birth of a transfusion dependent $\beta$-thalassemia child. After identification of a carrier couple by HPLC test, an option for such a couple is prenatal diagnostic tests ${ }^{[15]}$. Prenatal diagnostic tests in an anxious couple of an affected child or child expired due to thalassemia; offers a positive impact during next pregnancy. This forms the basis of thalassemia prevention programmes. In present study it was not possible to differentiate $\beta^{0} \beta^{0}, \beta^{+} \beta^{+}, \beta^{0} \beta, \beta^{+} \beta$, $\beta^{0} \beta^{+}$and other genotypes. Genetic study is essential for these cases.

Hence, this study emphasises the need of community based targeted study and field work. So, health care resources can be planned accordingly, to reduce the burden of thalassemia in India.
Conflict of interest: None.

\section{References}

1. Galanello R, Origa R. Beta-thalassemia. Orphanet Journal of Rare Diseases.2010 May 21; 5:11.

2. Manglani M, Lokeshwar MR, Vanis VG, Bhatia N, Mhaskar V. 'NESTROFT'--an effective screening test for beta thalassemia trait. Indian_Pediatrics.1997 Aug; 34(8):702-7

3. Colah RB, Surve R, Sawant P, D'Souza E, Italia K, Phanasgaonkar $\mathrm{S}$ et al.HPLC studies in hemoglobinopathies.Indian Journal of Pediatrics. 2007 July; 74(7): 657-62

4. Rangan A, Handoo A, Sinha S, Saxena R, Verma IC, Kumar S et al. Utility of family studies in diagnosing abnormal hemoglobins/ thalassemic states. Indian Journal of Pediatrics. 2009 June; 76(6):615-21

5. Sachdev R, Dam AR, Tyagi G. Detection of $\mathrm{Hb}$ variants and hemoglobinopathies in Indian population using HPLC: report of 2600 cases. Indian J Pathol Microbiol.2010 Jan-Mar; 53(1):57-62

6. Rao S, Kar R, Gupta SK, Chopra A, Saxena R. Spectrum of haemoglobinpathies diagnosed by cation exchangeHPLC \& modulating effects of nutritional deficiency anaemias from north India. Indian J Med Res. 2010 Nov; 132:513-9

7. Patel J, Patel A, Patel J, Kaur A, Patel V.Prevalence Of Haemoglobinopathies In Gujarat, India: A Cross-Sectional Study. The Internet Journal of Hematology.2009; $5(1)$.

8. Ambekar SS, Phadke MA, Mokashi GD, Bankar MP, Khedkar VA, Venkat V, Basutkar DG. Pattern of haemoglobinopathies in western Maharashtra.Indian Pediatr.2001 May; 38(5):530-4

9. Shah Sejal J, Chauhan Sanjay C, Rathod Hitesh K, Patel Amul B, Sharma Vaibhavi Y.A profile of cases of hemoglobino- 
pathies at a Medical college. National Journal of Medical Research.2012 AprJune; 2(2):137-140

10. Baig SM, Azhar A, Hassan H, Baig JM, Aslam M, Ud Din MA, Qureshi JA, Zaman T.Prenatal diagnosis of betathalassemia in Southern Punjab, Pakistan.Prenat Diagn. 2006 Oct; 26(10):903-5

11. Gonzalez-Redondo JM, Stoming TA, Lanclos KD, Gu YC, Kutlar A, Kutlar F et al. Clinical and genetic heterogeneity in black patients with homozygous betathalassemia from the southeastern United States.Blood.1988 Sep; 72(3):1007-14

12. Chandrashekar V, Soni M.Haemoglobin disorders in South India.ISRN Hematol.2011; 2011:1-6

13. Fucharoen S, Winichagoon $P$, Wisedpanichkij R, Sae-Ngow B, Sriphanich R, Oncoung W et al.Prenatal and postnatal diagnoses of thalassemias and hemoglobinopathies by HPLC.Clin Chem. 1998 Apr; 44(4):740-8

14. Jha BM, Bhavna Gamit, Jitendra Patel, Prajapati KJ. Hemoglobin E disorders in South Gujarat: A study of 35 cases. Nat J Comm Med. 2012; 3(1):66-70.

15. Traeger-Synodinos J, Harteveld CL, Old JM, Petrou M, Galanello R, Giordano P et al. EMQN Best Practice Guidelines for molecular and haematology methods for carrier identification and prenatal diagnosis of the haemoglobinopathies. Eur J Hum Genet. 2015 Apr; 23(4):426-37.doi: 10.1038/ejhg.2014.131. Epub 2014 Jul 23. 